\title{
Chronic itch by neuron-glia interactions in the spinal dorsal horn
}

\author{
Makoto Tsuda \\ Department of Life Innovation, Graduate School of Pharmaceutical Sciences, Kyushu University
}

\begin{abstract}
Itch sensation is a defense system that responds rapidly to a wide range of harmful internal and external stimuli. Recent progress in our understanding of the neuronal basis for itch sensation in the nervous systems has been made, but the mechanism underlying how itch turns into a pathological chronic state, such as atopic dermatitis, remains poorly understood. It is becoming clear that chronic itch is not simply a consequence of the continuity of acute itch signals, but rather of maladaptive function in the nervous system that is caused by long-term structural and functional alterations following skin inflammation. Recent studies have uncovered the causal role of glial cells in the spinal dorsal horn using mouse models of chronic itch including atopic dermatitis. Understanding the key roles of neuron-glia interactions may provide us with exciting insights into the mechanisms for the chronicity of itch and clues to develop novel therapeutic agents for treating chronic itch.
\end{abstract}

Keywords

Chronic itch; Spinal dorsal horn; Neuronal circuits; Astrocytes; Microglia

Received: 10 November 2018

脊喊後角の神経・グリア相互作用が作り出す慢性择痒

津田 誠

九州大学 大学院薬学研究院 ライフイノベーション分野

\section{はじめに}

痒みは，掻きたいという欲望を起こさせる不 快な感覚で, 皮虐に付着・侵入する外敵を引掻 き行動で除去するといった生体防御的な役割が 想定されている。通常，痒みは掻痒部位への引
掻きにより軽減するが，一方，アトピー性皮膚 炎などの皮膚疾患では，棒みは慢性化し，反復 的な引掻きによる皮膚炎の悪化，その結果，更 なる痒みを生むという悪循環に陥ってしまう。 したがって, 痒みの発生や伝達の仕組みの解明 は, 生物の生体防御機構の理解と, 慢性择痒又 
カニズムの解明および創薬シーズの発見に繋が る重要な課題である。

本稿では, 痒み選択的な神経伝達機構と, ア トピー性皮䖉炎などに伴う慢性的な痒みの基礎 研究から得られた知見の中から脊㖪後角の神 経・グリア相互作用による慢性掻痒メカニズム を中心に紹介する。

\section{痒みの神経伝達経路}

従来，痒みは単なる弱い痛み信号で起こる と想定されてきたため, 痒みの神経化学的理 解は非常に遅れている。そのような中，神経 ペプチドのガストリン放出ペプチド (GRP) が 痒み行動を選択的に誘発すること, GRP 受容 体 (GRPR) 欠損マウスで痒み行動が減弱する こと ${ }^{15)}$, さらに, GRPR 陽性 $\left(\mathrm{GRPR}^{+}\right.$: 以降, 陽性を「+」と記載する) 脊䯣後角神経をサポリン によって除去したマウスで痒み行動が抑制され ることが発見された 16$)$ 。特記すべきは，これら の欠損マウスや処置によって痛み行動には影響 がなかった点である。したがって，GRPR 神 経を中心とした痒み選択的な脊䯣後角神経回路 の存在が明らかになった（Fig.1）。また，GRP による痒みは霊長類でも認められる ${ }^{8)}$ 。当初, GRP は一次求心性神経より放出されるとされ ていたが 15)，その後の研究からその放出源は脊 剈道後角介在神経であろうとされている3) (Fig.1)。GRP+ 神経は B 型ナトリウム利尿ペプ チド（Nppb）によって活性化される10)。GRP ${ }^{+}$ 神経には棒及選択的な一次求心性神経 $\left(\mathrm{MrgprA3}^{+}\right)$も直接入力している ${ }^{14)}$ (Fig.1)。 一方で，GRP-GRPR シグナルを抑制性に制御 する介在神経として，転写因子 Bhlhb5で規定 される神経サブセットがある ${ }^{12)}$ 。 Bhlhb5+神経 はダイノルフィン+と神経型一酸化窒素合成酵
素 ${ }^{+}\left(\mathrm{nNOS}^{+}\right)$に分類できるが，痒みの抑制には 前者が関与している4)。ダイノルフィン+神経 はソマトスタチン (SST) 受容体タイプ 2 を発現 し，SST により過分極が起こり，痒みが誘発さ れる 4,7)。SST は, $\mathrm{Nppb}^{+}$一次求心性神経と脊 髄後角神経に発現する。また，抑制性神経伝達 物質 GABA も棒みの制御に深くかかわる。筆 者らは小胞型 GABA トランスポーター $\mathrm{VGAT}^{+}$ の脊髄後角抑制性介在神経を特異的に活性化す ることで慢性掻痒が著明に抑制されることを示 した6)。さらに最近， $a 2$ と $a 3$ サブユニットを 含む GABAA 受容体の活性化が痒みを効果的に 抑制することが示された ${ }^{11) 。 ~}$

通常痒みを起こさない触刺激などで起こる痒 みはアロネーシスと呼ばれ，上記の神経経路と は別の経路を介している可能性が示唆されてい る。その候補として春䯣後角抑制性介在神経の NPY-Cre ${ }^{+}$神経が挙げられる1)。この神経サブ セットはニューロペプチドY (NPY) プロモー ター制御下で Cre を発現するトランスジェニッ クマウスから見出され，同マウスの脊䯣後角 Cre 発現神経である。実際に, 同神経を選択的 に除去あるいは人工的に抑制することで，軽い 機械刺激による痒みが誘発される。しかし，化 学性の刺激による痒み，および痛みには全く影 響がない。また最近，老齢マウスとドライスキ ンマウスでメルケル細胞が減少し，それがアロ ネーシスに関与することが報告された ${ }^{2)}$ 。メル ケル細胞や Piezo2 の欠損によってアロネーシ スが再現でき，ケモジェネティックスによるメ ルケル細胞の人工的刺激によりドライスキンの アロネーシスが抑制された。したがって，メル ケル細胞から低閾值機械受容器を介したシグナ ルが，NPY-Cre+ ${ }^{+}$神経活動を調節している可能 性がある (Fig.1)。 


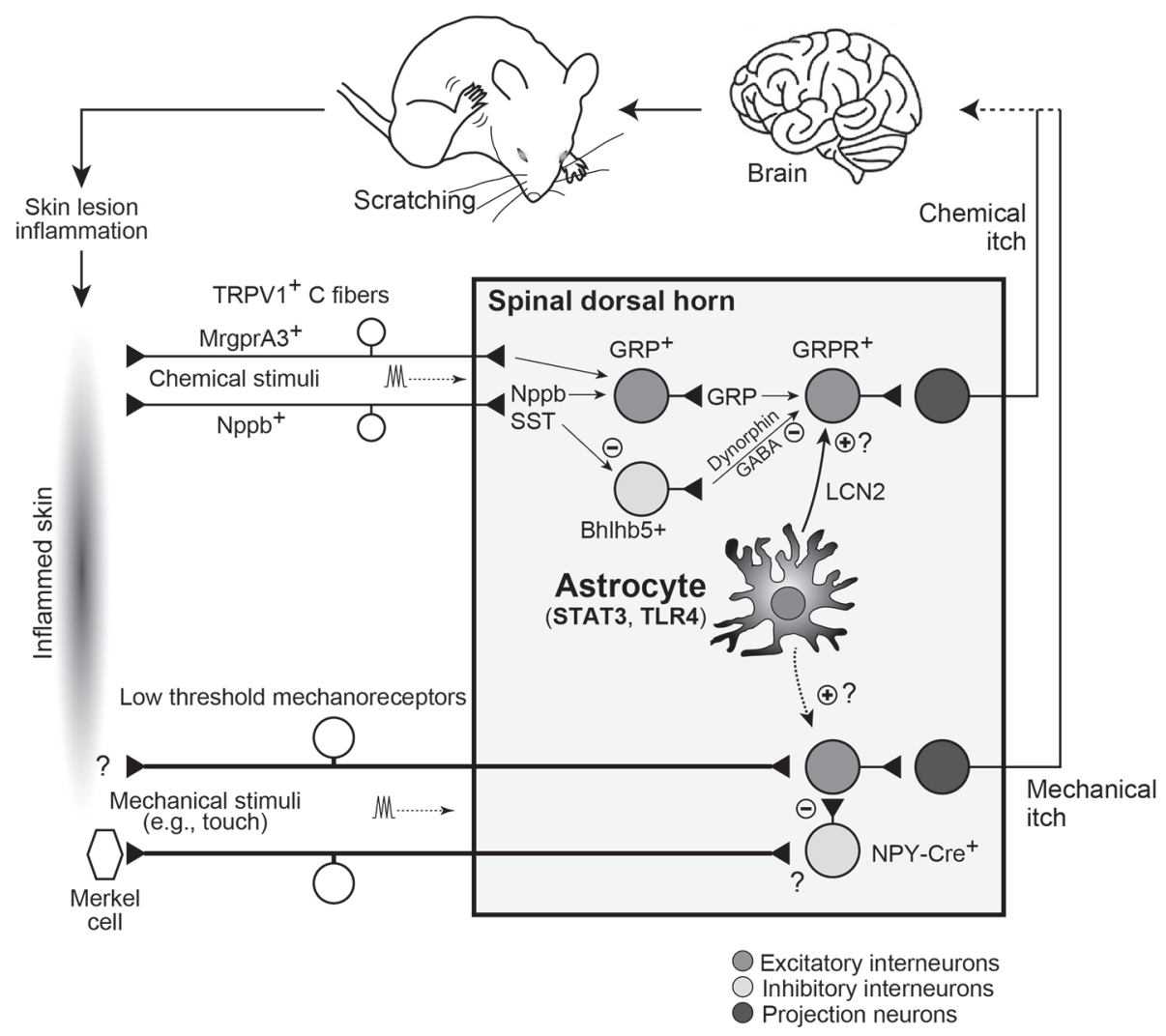

Fig.1 Neuronal circuits for itch and the role of astrocytes in chronic itch.

Chemical pruritogens activate that express $\mathrm{MrgprA}^{+}$and $\mathrm{Nppb}^{+}$primary afferents, which in turn leads to activation of $\mathrm{GRP}^{+}$dorsal horn interneurons. The released GRP acts on GRP receptors (GRPR) expressed in a subpopulation of dorsal horn interneurons. GRPR ${ }^{+}$ neurons are controlled by Bhlhb5+ inhibitory interneurons through GABA and dynorphin. SST inhibits Bhlhb5 ${ }^{+}$interneurons. As for mechanical itch, NPY-Cre interneurons play an inhibitory role. For alloknesis, a neuronal pathway from Merkel cells in the skin to NPY-Cre interneurons through a subset of low threshold mechanoreceptors is hypothesized to have an inhibitory role. Under chronic itch conditions, dorsal horn astrocytes are activated via STAT3- and TLR4-dependent signals. Reactive astrocytes produce and release LCN2. LCN2 may sensitize GPR-GRPR signaling. Reactive astrocytes may also influence an alloknesis pathway involving NPY-Cre ${ }^{+}$dorsal horn interneurons. Astrocytederived itch sensitization leads to excessive scratching, worsening skin lesions, which maintains enhanced astroglial reactivity. Therefore, a neuron-glial interaction critically might contribute to the vicious cycle of itching and scratching, and to chronic itch.

\section{慢性掻痒と春髄後角アストロサイト}

従来，グリア細胞は神経に対する単なる受動

的補助細胞として認識されてきたが，筆者らは 慢性疼痛モデル等を用いた基礎研究から，神経 とグリア（特にアストロサイトとミクログリア）
による脊髄後角異種細胞ネットワークが感覚情 報の適切な処理・統合に重要であることを世界 に先駆けて示してきた5)。最近筆者らは，自然 発症のアトピー性皮膚炎モデルマウスの脊䯣後 角において，アストロサイトが著明に活性化し ていることを見出した13)。アストロサイトは， 
Neuron-glia interactions and chronic itch

脳や脊髄におけるグリア細胞の中で数が最も多 く, 細胞突起でシナプスの構造を維持すること に加え，神経からのシグナルを受けグリオトラ ンスミッターを放出して神経活動を調節する (三者間シナプス)。アトピーマウスでアストロ サイトが活性化する脊髄後角は，引掻き行動が 多発する皮虐（顔面や上背部）の神経支配領域 と一致し，アストロサイトの活性化と皮䖉炎の タイムコースに相関性が認められた。炎症皮膚 では，一次求心性神経 C 線維が表皮内侵入する が 17)，同線維を減少させたアトピー性皮膚炎マ ウスではアストロサイトの活性化が抑制され た 13)。したがって，皮膚の炎症や物理的刺激に より，表皮内侵入した神経線維が活性化し，そ のシグナルでアストロサイトが活性化する可能 性がある。さらに，アストロサイトの活性化に は転写因子 STAT3 が重要な役割を担う。事実, STAT3 の活性化阻害でアストロサイトの活性化 と慢性掻痒が共に抑制される ${ }^{13)}$ 。また，アト ピー性皮膚炎マウスでは GRPR を介する痒みが 増強するが，その現象も活性化アストロサイト を抑制することで正常化する。したがって， STAT3 によって活性化したアストロサイトが脊 髄後角での GRP-GRPR 痒みシナプス伝達を増 強し, 慢性掻痒を増悪させていることが示唆さ れる。さらに, 活性化アストロサイト由来の㾕 み増強因子としてリポカリン $2(\mathrm{LCN} 2)$ を特定 した ${ }^{13)}$ 。脊䯣後角アストロサイト特異的に LCN2 をノックダウンすることで痒みが有意に 低下し，また，LCN2 は GRP による痒みを増 強する 13)。以上より，STAT3 依存的にアストロ サイトで発現増加する LCN2 が, 脊髄後角 GRP-GRPR シグナルを介する痒みを増強し， 慢性掻痒に重要な役割を果たしていると考えら れる (Fig.1)。

\section{脊髄後角アストロサイトとアロネーシス}

ドライスキンモデルの脊髄後角で Toll 様受容 体 4（TLR4）の発現がアストロサイト選択的に 増加し, TLR4 の欠損や阻害によって自発的な 痒みおよびアロネーシスが抑制される9)。この 結果は，慢性掻痒に扔ける脊髄後角アストロサ イトの役割を支持し，アストロサイトがアロ ネーシスにも関与している可能性を示唆してい る。アロネーシスは化学性の痒みとは異なる神 経経路を介するため，アロネーシス経路に対す るアストロサイトからの新しい調節機構が存在 する可能性が予想され，大変興味樑い。

\section{慢性掻痒と脊䜔後角ミクログリア}

脊䯣後角におけるミクログリアの形態学的活 性化が複数の慢性掻痒モデルで報告されてい る 18,19)。脊髄後角ミクログリアでは CX3CR1 を 介して p38MAPKがリン酸化され, p38MAPK 阻害剂で痒みが抑制されることから，慢性掻痒 におけるミクログリアの関与が示唆される。ま た，慢性掻痒はミノサイクリンでも抑制され る 18,19)。しかし，慢性掻痒モデルでのミクログ リアの活性化と $\mathrm{p} 38 \mathrm{MAPK}$ 阻害薬の抑制効果は, ある特定の時期のみで認められるため, ミクロ グリアの役割は痒みの慢性化プロセスの中で限 局的なものかもしれない。また，慢性择痒モデ ルにおけるミクログリアの形態学的変化におい ても一致した見解は得られていない9,13)。

\section{おわりに}

アトピー性皮膚炎などに伴う慢性的な痒みは これまで主に皮膚を中心に研究されてきたが, 今回筆者らは，その研究の視点を中枢神経系に 
向けたことで，春髄後角アストロサイトという 痒みの慢性化メカニズムにおける新しい役者を 見つけることができた。この成果から，アスト ロサイトを標的にした治療薬の開発に繋がる可 能性がある。今後, どのようにアストロサイト が活性化し痒み信号を増強するのか，また痒み はどのように伝達されるのかなど，まだまだ多 くの課題が残されているが，それらを基礎研究 から一つ一つ明らかにし，痒みを感じる仕組み とその慢性化のメカニズムを解明し，新しい治 療薬の創製に慗げたい。

\section{文 献}

1) Bourane, S., Duan, B., Koch, S.C., Dalet, A., Britz, O., Garcia-Campmany, L., Kim, E., Cheng, L., Ghosh, A., Ma, Q., Goulding, M., Gate control of mechanical itch by a subpopulation of spinal cord interneurons, Science, 350 (2015) 550-554.

2) Feng, J., Luo, J., Yang, P., Du, J., Kim, B.S., Hu, H., Piezo2 channel-Merkel cell signaling modulates the conversion of touch to itch, Science, 360 (2018) 530-533.

3) Gutierrez-Mecinas, M., Watanabe, M., Todd, A.J., Expression of gastrin-releasing peptide by excitatory interneurons in the mouse superficial dorsal horn, Mol. Pain, 10 (2014) 79.

4) Huang, J., Polgar, E., Solinski, H.J., Mishra, S.K., Tseng, P.Y., Iwagaki, N., Boyle, K.A., Dickie, A.C., Kriegbaum, M.C., Wildner, H., Zeilhofer, H.U., Watanabe, M., Riddell, J.S., Todd, A.J., Hoon, M.A., Circuit dissection of the role of somatostatin in itch and pain, Nat. Neurosci., (2018).

5) Inoue, K., Tsuda, M., Microglia in neuropathic pain: cellular and molecular mechanisms and therapeutic potential, Nat. Rev. Neurosci., 19 (2018) 138-152.

6) Kanehisa, K., Shiratori-Hayashi, M., Koga, K., Tozaki-Saitoh, H., Kohro, Y., Takamori, K., Tsuda, M., Specific activation of inhibitory interneurons in the spinal dorsal horn suppresses repetitive scratching in mouse models of chronic itch, J. Dermatol. Sci. 88 (2017) 251254.

7) Kardon, A.P., Polgar, E., Hachisuka, J., Snyder, L.M., Cameron, D., Savage, S., Cai, X., Karnup,
S., Fan, C.R., Hemenway, G.M., Bernard, C.S., Schwartz, E.S., Nagase, H., Schwarzer, C., Watanabe, M., Furuta, T., Kaneko, T., Koerber, H.R., Todd, A.J., Ross, S.E., Dynorphin acts as a neuromodulator to inhibit itch in the dorsal horn of the spinal cord, Neuron, 82 (2014) 573586.

8) Lee, H., Ko, M.C., Distinct functions of opioidrelated peptides and gastrin-releasing peptide in regulating itch and pain in the spinal cord of primates, Sci. Rep., 5 (2015) 11676.

9) Liu, T., Han, Q., Chen, G., Huang, Y., Zhao, L.X., Berta, T., Gao, Y.J., Ji, R.R., Toll-like receptor 4 contributes to chronic itch, alloknesis, and spinal astrocyte activation in male mice, Pain, 157 (2016) 806-817.

10) Mishra, S.K., Hoon, M.A., The cells and circuitry for itch responses in mice, Science, 340 (2013) 968-971.

11) Ralvenius, W.T., Neumann, E., Pagani, M., Acuna, M.A., Wildner, H., Benke, D., Fischer, N., Rostaher, A., Schwager, S., Detmar, M., Frauenknecht, K., Aguzzi, A., Hubbs, J.L., Rudolph, U., Favrot, C., Zeilhofer, H.U., Itch suppression in mice and dogs by modulation of spinal alpha2 and alpha3GABAA receptors, Nat. Commun., 9 (2018) 3230.

12) Ross, S.E., Mardinly, A.R., McCord, A.E., Zurawski, J., Cohen, S., Jung, C., Hu, L., Mok, S.I., Shah, A., Savner, E.M., Tolias, C., Corfas, R., Chen, S., Inquimbert, P., Xu, Y., McInnes, R.R., Rice, F.L., Corfas, G., Ma, Q., Woolf, C.J., Greenberg, M.E., Loss of inhibitory interneurons in the dorsal spinal cord and elevated itch in Bhlhb5 mutant mice, Neuron, 65 (2010) 886-898.

13) Shiratori-Hayashi, M., Koga, K., Tozaki-Saitoh, H., Kohro, Y., Toyonaga, H., Yamaguchi, C., Hasegawa, A., Nakahara, T., Hachisuka, J., Akira, S., Okano, H., Furue, M., Inoue, K., Tsuda, M., STAT3-dependent reactive astrogliosis in the spinal dorsal horn underlies chronic itch, Nat. Med., 21 (2015) 927-931.

14) Sun, S., Xu, Q., Guo, C., Guan, Y., Liu, Q., Dong, X., Leaky Gate Model: Intensity-Dependent Coding of Pain and Itch in the Spinal Cord, Neuron, 93 (2017) 840-853 e845.

15) Sun, Y.G., Chen, Z.F., A gastrin-releasing peptide receptor mediates the itch sensation in the spinal cord, Nature, 448 (2007) 700-703.

16) Sun, Y.G., Zhao, Z.Q., Meng, X.L., Yin, J., Liu, X.Y., Chen, Z.F., Cellular basis of itch sensation, Science, 325 (2009) 1531-1534. 
17) Tominaga, M., Takamori, K., Itch and nerve fibers with special reference to atopic dermatitis : therapeutic implications, J. Dermatol., 41 (2014) 205-212.

18) Torigoe, K., Tominaga, M., Ko, K.C., Takahashi, N., Matsuda, H., Hayashi, R., Ogawa, H., Takamori, K., Intrathecal Minocycline Suppresses Itch-Related Behavior and Improves Dermatitis in a Mouse Model of Atopic Dermatitis, J. Invest. Dermatol., 136 (2016) 879-881.

19) Zhang, Y., Yan, J., Hu, R., Sun, Y., Ma, Y., Chen, Z., Jiang, H., Microglia are involved in pruritus induced by DNFB via the CX3CR1/p38 MAPK pathway, Cell. Physiol. Biochem., 35 (2015) 1023-1033.

Address for correspondence: Makoto Tsuda Department of Life Innovation, Graduate School of Pharmaceutical Sciences, Kyushu University 3-1-1 Maidashi, Higashi-ku, Fukuoka 812-8582, Japan

※ 本稿は第 40 回日本疼痛学会 (2018 年 7 月, 長崎) 「シンポジゥム 3 : 痒みのトランスレーショナル神 経生物学 〜げっ歯類からヒトまで」の講演内容を まとめたものである。 